\title{
EXECUTION AGAINST A DEBTOR'S HOME IN TERMS OF ROMAN-DUTCH LAW AND THE CONTEMPORARY SOUTH AFRICAN LAW: COMPARATIVE OBSERVATIONS
}

\section{Lienne Steyn***}

\section{ABSTRACT}

Relatively recently, fundamental changes, not only in the law, but also in policy and judicial approach, have occurred in the context of debt enforcement by execution against a debtor's home. These have been the product of the recognition of the right to have access to adequate housing, provided by section 26 of the Constitution of the Republic of South Africa, 1996, and the regulation by the National Credit Act 34 of 2005 of debt enforcement procedures against consumers in credit transactions, including mortgage bond agreements.

South African common law principles applicable to mortgage bonds and applicable in the context of execution against a mortgagor's immovable property that constitutes his or her home, are rooted in Roman-Dutch law. Certain RomanDutch procedural rules and practices may be identified as having generally tended towards affording a measure of protection for the home of a debtor against execution by a creditor. These were rules which, for example, encouraged extra-judicial

* Associate Professor, School of Law (Howard College Campus), University of KwaZulu-Natal.

** This article is based on and contains extracts from L Steyn Statutory Regulation of Forced Sale of the Home in South Africa (LLD, University of Pretoria, 2012). 
settlement negotiations and required personal service of summonses, four defaults before default judgment could be obtained in respect of a claim involving immovable property, and a more protracted procedure for execution against immovable, as opposed to movable, property. Exacting requirements were also imposed in order to maximise the price obtained at a judicial sale of immovable property. The same procedural rules and practices were not evident in the pre-Bill of Rights South African law. However, they may be viewed as being more in line with contemporary, constitutional imperatives, as well as law reform initiatives, to balance the various rights applicable in the context of execution against a debtor's home and to ensure that execution against a debtor's home may occur only as a last resort, where there are no alternative means by which the debt may be satisfied.

Keywords: Roman-Dutch; debt enforcement; mortgage bond; execution; home mortgage foreclosure; right to have access to adequate housing; section 26 of the Constitution; the National Credit Act

\section{Introduction}

Recently reported judgments, in matters concerning execution against a debtor's home, reflect the fundamental changes that have occurred in South Africa, not only in the law applicable in this context, but also in policy and judicial approach. These developments have been the product of the recognition of socio-economic rights and, most significantly, the right to have access to adequate housing, provided by section 26 of the Constitution of the Republic of South Africa, 1996. ${ }^{1}$ The Constitutional Court's judgments in Jaftha v Schoeman; Van Rooyen v Stoltz, ${ }^{2}$ Gundwana v Steko Development $C C,{ }^{3}$ and Nkata $v$ FirstRand Bank Limited,${ }^{4}$ each of which gives effect essentially to section 26 rights, reflect ground-breaking changes in the treatment of a creditor's, including a mortgagee's, entitlement to enforce its claim by executing against immovable property that constitutes the debtor's home. The regulation by the National Credit Act 34 of $2005^{5}$ of debt enforcement procedures against consumers in credit transactions, including mortgage bond agreements, has also had a significant impact on home mortgagors' and mortgagees' rights. This is borne out by the case of Nkata v Firstrand Bank Limited, ${ }^{6}$ which illustrates the marked difference between

1 Hereafter referred to as the Constitution.

2 Jaftha v Schoeman; Van Rooyen v Stoltz 2005 (2) SA 140 (CC), hereafter referred to as Jaftha v Schoeman.

3 Gundwana v Steko Development CC 2011 (3) SA 608 (CC), hereafter referred to as Gundwana v Steko.

$4 \quad$ Nkata $v$ FirstRand Bank Limited 2016 (4) SA 257 (CC), hereafter referred to as Nkata $v$ FirstRand Bank (CC).

5 Hereafter referred to as the NCA.

6 See Nkata $v$ FirstRand Bank (CC) at par 100 and the judgment of Rogers J, in the court a quo, reported as Nkata $v$ FirstRand Bank Limited 2014 (2) SA 412 (WCC), hereafter referred to as Nkata $v$ FirstRand Bank (WCC) at par 53. 
a defaulting mortgagor's right to "reinstatement" of the agreement, in terms of the NCA, and his or her right to "redemption" of the mortgaged property, according to the South African common law, with Roman-Dutch legal principles as its source. ${ }^{7}$

The position regarding execution against a debtor's home, in Roman times, was considered in an earlier issue of this journal. ${ }^{8}$ This article will consider the relevant Roman-Dutch law, as it applied in Holland ${ }^{9}$ and as later received into the Cape Colony in the seventeenth century. ${ }^{10}$ Taking into account recent developments, some comparisons will be drawn between the position in Roman-Dutch law and in contemporary South African law.

\section{Roman-Dutch law}

\section{General background}

Roman-Dutch law may be regarded as having existed as soon as Germanic custom incorporated elements derived from Roman law. This may be traced back to the time when the Codex Theodosianus of $438 \mathrm{AD}$ influenced tribal customs in the regions now known as Holland and Belgium. ${ }^{11}$ After the Frankish Empire dissolved in 900 $\mathrm{AD}$, no general legislation was passed for a number of centuries. The Counts of Holland issued local handvesten (privileges) in their towns which were, in many respects, at variance with one another. As a result, Roman law, regarded as "a system logical, coherent and complete", ${ }^{12}$ was received in some of the provinces of the Dutch Netherlands. Ordinances passed by municipalities also formed part of the law. Charles V promulgated what have been referred to as "useful measures", ${ }^{13}$ such as the Placaat of 10 May 1529, relating to the transfer and hypothecation of immovable property, and the Perpetual Edict of 4 October 1540. Another significant ordinance was the Ordinance on Civil Procedure of $1580 .{ }^{14}$ By the end of the sixteenth century, the applicable law consisted of ordinances; handvesten; Roman-Dutch law, that is, "the ancient customs engrafted on the Roman law"; and Roman law as reflected in the Corpus Iuris Civilis as well as, in some cases, Canon law. ${ }^{15}$ This law was introduced to the colonies, including the Cape of Good Hope. ${ }^{16}$

7 See Nkata v FirstRand Bank (WCC) at par 53, with reference to Nedbank Ltd v Fraser and Four Similar Cases 2011 (4) SA 363 (GSJ), hereafter referred to as Nedbank v Fraser, at pars 40-41 and Brits 2013a: 167-168.

8 Steyn 2015: 119-141.

9 "Holland", in this context, is intended to bear the same meaning as that attributed to the term by Lee 1953: 2.

10 See par 3 infra.

11 Lee 1953: 3.

12 Ibid.

13 Lee 1953: 6.

14 See Erasmus 1996: 143. See, also, par 3 infra.

15 Wessels 1908: 206-207.

16 Lee 1953: 7. See, further, par 3 infra. 


\section{Debt enforcement}

According to Germanic custom, a debtor could be sold into slavery and, during the feudal regime, a debtor could be compelled to work for his creditor. ${ }^{17}$ Old Dutch handvesten permitted a debtor, who was unable to pay his creditor, to be handed over to him until the debt was paid..$^{18}$ Apparently, before the introduction of cessio bonorum, ${ }^{19}$ the law of Holland provided only for execution against the person. Later developments allowed execution against the debtor's property. Because litigation was complex, necessitating representation by attorneys and advocates, ${ }^{20}$ and because it was expensive, a plaintiff had first to claim satisfaction from the defendant in a friendly manner ${ }^{21}$ before he could institute action by serving summons. ${ }^{22}$ In the high court, the parties were required first to appear before a commissioner in an attempt to reach a compromise before a summons could be issued. The process server, when serving the summons, had also to explain to him the "exigency" of it. If the defendant wished to defend the matter, the process server would appoint a convenient day, between fourteen days and one month later, for him to appear. ${ }^{23}$

If the defendant did not appear on the return day, the plaintiff would "pray default". In an ordinary action, four defaults were required. After each default, the defendant was afforded the benefit of a subsequent writ or summons until, after the fourth default, the court would grant judgment against him. ${ }^{24}$ In a defended matter,

17 Wessels 1908: 664 observes that later legal provisions for civil imprisonment were vestiges of this practice.

18 Idem 663 where the author refers to the Handvest of Alkmaar of 1254. See, also, Calitz 2010: 9.

19 Exactly when cessio bonorum was introduced is unclear. See Bertelsmann et al 2008: 8, where the authors refer to authoritative views that it was not in use before 1288; $c f$ Van der Keessel 1884: 883, who indicates that it was in use towards the end of the fifteenth century. See, also, Wessels 1908: 218 \& 663-664. Cessio bonorum, which may be regarded as the predecessor to the voluntary surrender process in South African insolvency law, entailed full disclosure of the position of the debtor's estate in a petition to court, with notice to creditors. Briefly, it prevented the arrest of the debtor and effected a stay of execution against his assets. The debtor was entitled to rely on the beneficium competentiae to retain certain assets including his clothes, bedding, tools and other necessities of life such as items which might enable him to earn a living. The estate was initially administered by commissioners under the supervision of local magistrates (scout and schepenen). Cessio bonorum will not be discussed further as this article is concerned with the individual debt enforcement procedures. For more detail, see Voet 1957: 423 7; Wessels 1908: 663-666; Bertelsmann et al 2008: 8; Grotius 1903: 3 51 2; Van der Linden 1891: 372 ; van der Keessel 1884: 884 \& 889. See, also, Roestoff 2002: 51-52; Roestoff 2005: 78 \& 81; Evans 2008: 42-43; and Calitz 2009: 24-25.

20 Van der Linden 1891: 324.

21 Either orally or in writing, or by notarial demand.

22 Van der Linden 1891: 32 1. On service of summons, see Van der Linden 1891: 326.

23 Idem 329 . On the return day, the plaintiff's attorney had to file a declaration setting out the claim: see Van der Linden 1891: 3212.

24 Idem 32 13. If the defendant appeared on the second or third summons, he could apply to purge the defaults, but if he appeared only on the fourth summons, he was required to obtain a writ of relief. 
once the substantive and procedural requirements ${ }^{25}$ had been complied with and a valid judgment had been granted, ${ }^{26}$ it had to be declared executable. In the lower courts, the judgment had to be placed in the hands of the messenger. In the high court, a writ of execution of the judgment had to be taken out at the registrar's office giving authority to the process server to execute it. ${ }^{27}$

The process server or messenger had to deliver to the execution debtor a document, known as the sommatie, calling upon him to satisfy the judgment debt, together with costs, within twenty-four hours ${ }^{28}$ failing which a renovatie, ${ }^{29}$ or alias writ, was issued. ${ }^{30}$ The process server or messenger, on serving the renovatie, would demand that property should be pointed out to him by the judgment debtor. It was the duty of the former to take movable property sufficient to satisfy the judgment debt. ${ }^{31}$ On the other hand, if despite diligent enquiry the process server or messenger did not find sufficient movable property to satisfy the judgment debt, he had to levy execution upon the immovable property. However, he was not entitled to levy execution upon immovable property of great value for small debts unless it could not be divided. ${ }^{32}$

In the lower courts, after the immovable property was attached, its sale had to be publicly announced on four Sundays and market days, in the towns, and on four Sundays and court days, in the country, with placards having to be posted in the nearest town. Once the sale had been held and the purchase price had been paid, a deed of transfer was granted to the purchaser by the lower court. ${ }^{33}$

In the high court, execution against immovable property entailed a more complex process.$^{34}$ Once the immovable property was attached in the presence of the schepenen, ${ }^{35}$ notice was given both to the execution debtor and to the lower court. The process server publicised the sale by issuing proclamations on four Sundays and market days and, on the appointed day, he provisionally sold the property to the highest bidder. Thereafter, he had to summons all interested persons to the high court and to annex returns of service to the judgment and the writ of execution. On the appointed day, the execution creditor had to file his claim at the Rolls of the High Court for it to issue a decree of transfer which would confirm the sale after which

25 For a matter to be rendered "ripe for judgment", see Van der Linden 1891: 3210,33 \& 38.

26 It had to have been pronounced or delivered publicly; see Van der Linden 1891: 394.

27 Van der Linden 1891: 395.

28 Idem at 396 . In the high court, the sommatie set out what was required of the judgment debtor and a copy of the judgment and the writ of execution were also delivered to him.

29 This was a repetition of the sommatie.

30 Van der Linden 1891: 397.

31 Idem at $399 \& 3910$.

32 Idem at 3911.

33 Ibid.

34 Idem at 3912.

35 The schepenen were administrative and judicial officials; see Bertelsmann et al 2008: 8. 
nobody could oppose it. ${ }^{36}$ A certificate, or deed of proclamation, was drawn up in the registrar's office calling on all persons to appear at the high court on a certain day if they wished to make a higher bid for the immovable property than that already received. The process server published the deed of proclamation by posting placards announcing the final sale.

On the advertised day, the property was de novo publicly put up for sale at the Rolls of the High Court by the assistant registrar, or secretary in charge of the Rolls, and knocked down to the highest bidder. Thereafter, a ceremony took place in which the oldest commissioner of the Rolls held in his hand the deed of transfer with the court's seal attached to it and he removed the court's seal, thus signifying that the property had been adjudicated to the highest bidder or, when there were no further bids for the property, to the purchaser. ${ }^{37}$ The proceeds of the sale of the immovable property had to be paid to the secretary of the lower court or to the registrar of the high court, as the case might be, and payment to the creditor was regulated from there. ${ }^{38}$

If the judgment debtor did not have property or had property insufficient to satisfy the judgment debt, the judgment creditor was permitted to proceed against his person. ${ }^{39} \mathrm{~A}$ debtor could evade imprisonment by relying on the beneficium competentiae which entitled him to retain an amount adequate for his maintenance according to his craft and standing. ${ }^{40}$

\section{Real security}

Mortgage, ${ }^{41}$ as defined by Grotius, is a "right over another's property which serves to secure an obligation". ${ }^{42}$ The ancient form of German pledge was not an accessory agreement but more a kind of "alternative payment" whereby the debtor delivered to the creditor, as provisional payment, something different from the object promised and which he could "redeem" once he performed his obligation. The debtor could choose not to perform what he had promised but to allow the object to remain with

36 There was a set procedure to be followed if anyone wished to oppose it, although it appears that this rarely occurred; see Van der Linden 1891: 397.

37 Ibid.

38 Van der Linden 1891: 398.

39 Idem at 3914.

40 Discussed at n 19 supra. See Voet 1957: 42 1 46, with reference to D 42119 1; 5017173 \& 25 35 7. It was interesting that a nobleman was entitled to more than a common person and an old man was entitled to more than a youth because it was easier for the latter to obtain a livelihood; see D $422636 \&$ D 24315.

41 Note that Gane explains, in Voet 1957: vol 3 at 470, with reference to Voet 20 1, that, although, strictly speaking, the term "mortgage" was not used in the Dutch law, the proper term to be used being "hypothec", for the sake of convenience, he makes reference to "mortgage" of immovable property in this context.

42 Lee 1953: 183, with reference to Grotius 2481. 
the creditor as fulfilment of their agreement. Further, if the creditor sold the object to a third party the debtor could not reclaim it. These aspects indicate that the creditor was regarded as the owner of the thing "pledged" and that, in a sense, credit was in fact not granted. ${ }^{43}$

In time, the Roman law principles relating to pignus and hypotheca were adopted so that by the time of Grotius the law of Holland, in relation to pledge, was similar to the Roman law of Justinian's time. ${ }^{44}$ Initially, when immovable property was pledged, the creditor became dominus with full usufruct of the land on the basis that he had promised to transfer the land back to the debtor once the debt was paid. If the debt was not paid within the stipulated time, the mortgagee remained the owner. However, in the thirteenth century the law was modified so that, if the mortgagor did not fulfil his obligation, the mortgagee could no longer treat the property as his own but he had to sell it by judicial sale. Wessels explains the position as follows: ${ }^{45}$

The Hollanders followed the Frisians, who adhered more strictly to the Roman law in not divesting the owner of his dominium in the thing mortgaged. The consequence of this was that the law of Holland was always favourable to the mortgagor, and its policy was to allow the debtor to recover the property pledged up to the time that it was actually sold in execution by judicial decree.

Wessels states that the extent to which the law of Holland protected the debtor is also evident from the fact that it did not recognise parate executie, which was a stipulation by which the debtor agreed to allow the creditor to sell the property pledged if the debt were not paid. ${ }^{46}$ Another prohibited agreement was a pactum commissorium, or agreement for forfeiture of the mortgaged property in the event of non-payment. ${ }^{47}$ However, where payment of the debt had to be made in a number of instalments or in a series of payments, it was permissible to agree that the pledged property could be sold in the event of default in respect of a single payment. ${ }^{48}$

43 This was based on the vadium contract; see Wessels 1908: 569-571 \& 592-593 who describes it as a type of contract of exchange.

44 Specific aspects, based on German custom, remained; see Wessels 1908: 593.

45 Idem 595-596.

46 Idem at 596. There is controversy as to whether the later law of Holland permitted parate executie. Lee 1953: 200-201, with reference to Voet 205 6, states that a parate executie agreement would not be enforced if the debtor afterwards objected, or if the private sale would be prejudicial to the other hypothecary creditors. Van der Keessel 1884: 439 states that a pledgee could sell the thing delivered to him if that was originally agreed upon. It may be noted that the translator, Lorenz, has qualified this statement by pointing out, with reference to D 874 , that it would be more accurate to translate the text as "where there has been no stipulation to the contrary".

47 Lee 1953: 200 with reference to Voet 20125.

48 Voet 205 1, with reference to Inst 3153 \& D 3313 . This is known as an acceleration clause, which is commonly employed in a modern day mortgage bond and which is discussed at par 43 infra. 
By the fourteenth century, the general practice was for the mortgagor to retain possession of his property. ${ }^{49}$ Thus, a deed of hypothecation became necessary as well as sufficient publicity for a mortgagee to be able to ascertain if property had already been mortgaged. To this end various placaaten were issued which effectively provided that a special mortgage of immovable property, including a kustingbrief ${ }^{50}$ was valid only if it was executed before the court and the required duty was paid. ${ }^{51}$ The holder of a validly executed special mortgage had a preferent claim on the proceeds arising from the sale of the mortgaged property. Where more than one special mortgage had been executed upon the same property, they would rank according to the order in which each was executed. ${ }^{52}$

To obtain the court judgment, which was required before a creditor could sell the mortgaged property, he had to have drawn up a confession of judgment by the debtor, ${ }^{53}$ or he had to issue a summons against the debtor requiring him to pay the debt or to appear to hear the mortgaged property being declared bound and executable. Once the judgment was obtained, the special mortgage was executed in compliance with certain requirements. ${ }^{54}$ Where mortgaged property was sold without the consent of the true owner, the latter could legally claim it from any person who was in possession of it without making restitution for the price paid by the latter. An exception to this rule was where goods were sold bona fide in the public market. In such a case, the price had to be restored..$^{55}$

Mortgage was extinguished by decree of court or by judicial sale or sale in insolvency of the mortgaged property. ${ }^{56}$ It could also be extinguished by prescription. ${ }^{57}$

49 Wessels 1908: 594.

50 A kustingbrief was a special mortgage of immovable property for the balance of its purchase price, the bond being passed at the time of transfer of the property; see Van der Linden 1891: 1123.

51 These included a Placaat of Charles V of 10 May 1529 and the Politique Ordonantie of 1580; see Wessels 1908: 217-218 \& 595. The Placaat der 40ste Penning of 22 Dec 1598 made duty of 2.5 per cent payable; see Lee 1953: 185; Van der Keessel 1884: 433.

52 A special mortgage enjoyed a claim preferent to that in respect of a prior general mortgage: see Van der Keessel 1884: 436; Lee 1953: 198; Van der Linden 1891: 1124.

53 Known as willige condemnatie. This was required in a case where the bond had been made subject to confession being signed.

54 Lee 1953: 200. Van der Linden 1891: 1125 states that the formalities were those required in the case of an onwillig Decreet which was "a sale of immovable property that took place by way of execution upon the order of the court; or, in a more general sense, a sale of the debtor's property, commenced by the Deurwaarder upon a judgment, and afterwards consummated at the High Court".

55 See Van der Keessel 1884: 183 n 3, with reference to S van Leeuwen Censura Forensis part I book iv ch $7 \S 17,184$. This rule applied in Holland, but not in Zeeland.

56 Voet 205 10, with reference to Mattheus II De Auctionibus Libri Duo, quorum prior Venditiones, posterior Locationes, quae sub hasta fiunt, exequatur: adjecto passim voluntarium auctionum jure 11411.

57 Van der Keessel 1884: 208. 


\section{Reception of Roman-Dutch law into the South African legal system}

In 1652, the Dutch East India Company established a refreshment station in the Cape of Good Hope for ships travelling between the Netherlands and the East Indies. The commander of the settlement, Jan van Riebeeck, established a rudimentary judicial system, at first administered by himself and his staff, applying the laws of the Province of Holland. These events led to the Cape Colony being established and the introduction of Roman-Dutch law into South Africa. ${ }^{58}$ In 1656, a Justitie ende Chrijghsraet was created to deal with legal matters. Except for the introduction of civil courts, called the courts of landdrosten and heemraden, for more remote areas outside Cape Town and the substitution of the Justitie ende Chrijghsraet with the Raad van Justitie, this basic structure of the administration of justice remained until the end of the first period of Dutch occupation of the Cape in 1795. ${ }^{59}$ Although the local government at the Cape issued placaaten, these were all repealed and RomanDutch law is generally regarded as the common law of South Africa. ${ }^{60}$ No rules of procedure were promulgated specifically for the Cape and it appears that the Raad van Justitie applied the Ordinance on Civil Procedure of $1580 .{ }^{61}$

As from 1795, the Cape was controlled by Britain. From 1803 to 1806, it was controlled again by Holland, or the Batavian Republic, as the Netherlands was then called. ${ }^{62}$ In 1803, the Batavian Republic appointed Jacobus Abraham de Mist as Commissioner-General of the Cape, who brought about significant changes, including the creation of a Desolate Boedelkamer for the administration of insolvent estates. It may be noted that, around 1805, in civil matters landdrosten "were required to use every endeavour to bring parties to amicable terms before proceeding to give judgment". ${ }^{63}$ Also, three defaults by a defendant were required before default judgment could be granted. This rule did not exist in later South African law. ${ }^{64}$

In 1806, Britain re-occupied the Cape, which became a British colony from 1815 until 1910 when the Union of South Africa was formed ${ }^{65}$ In 1818, the Desolate System and its Background (Cape Town, 1968) at 578. For a useful, succinct explanation of the reception of Roman-Dutch law in South Africa, see Glover 2003: 38 n 3. See, also, generally, De Vos 1992.

61 See Erasmus 1996: 143 n 15 \& 145. See par 21 supra.

62 From 1795 to 1806 , following its conquest by the French, the Netherlands was known as the Batavian Republic.

63 See Wessels 1908: 360.

64 Idem at 361.

65 See Fagan 1996: 46; De Vos 1992: $242 \mathrm{ff}$. 
Boedelkamer was abolished and replaced by a Sequestrator. In 1819, an Ordinance ${ }^{66}$ was promulgated in terms of which the office of the Sequestrator would be responsible, inter alia, for the execution of all civil sentences except those specially entrusted to the boards of landdrost and heemraden ${ }^{67}$

The British were dissatisfied with the administration of justice at the Cape and, after a commission enquired into the matter, in 1827, a Charter of Justice was issued which reshaped the judicial system along English lines. ${ }^{68}$ It provided, inter alia, for the replacement of the Raad van Justitie with an independent Supreme Court consisting of a Chief Justice and two puisne judges. This occurred in 1828. Full-time judges were imported from Britain. There was no Court of Chancery or Chancery jurisdiction and thus no separate courts of law and equity as there were in England. ${ }^{69}$ The courts of landdrost and heemraden were replaced by resident magistrates as in the English system. ${ }^{70}$ The Charter of Justice also established the post of Master of the Supreme Court. The office of the Sequestrator was abolished.

A second Charter of Justice, issued in 1832, came into effect in 1834. It provided for the retention of Roman-Dutch law as the law of the Cape Colony. ${ }^{71}$ The Supreme Court was given extensive powers to make rules for the practice and pleading in civil matters which "had to be framed 'so far as the circumstances of the ... Colony may permit, ... with reference to the corresponding rules and forms in use in ... [the] Courts of record at Westminster'." 72 This was significant for the development of South African civil procedure as a unique process in a mixed legal system. ${ }^{73}$ Further, Ordinance 72 of 1830 stipulated that the English rules of civil procedure were to apply in the courts. ${ }^{74}$ However, a number of Roman-Dutch remedies and concepts were retained. ${ }^{75}$ This is clearly evident in the South African law applicable in the context of execution against a debtor's home.

\section{South Africa}

\section{The position, pre-Constitution}

Traditionally, a debtor's home has not enjoyed specific protection against forced sale in the debt enforcement process. Statutory exemptions of specific classes of property

66 See Proclamation 2 of Sep 1819, referred to by Calitz 2009: 39.

67 See Calitz 2009: 39-40.

68 See Erasmus 1996: 146; Calitz 2009: 40; De Vos 1992: 244ff.

69 See Erasmus 1996: 146; Zimmerman 1996: 218-219.

70 Fagan 1996: 51.

71 See Erasmus 1996: 146; Girvin 1996: 96; Fagan 1996: 51.

72 See s 46 of the Charter of Justice, referred to by Erasmus 1996: 146-147; Fagan 1996: 51; De Vos 1992: 247-248.

73 See Zimmermann 1996: 217; De Vos 1992: 248-249; Erasmus 1991: 265-276.

74 Eckard 1990: 1.

75 See Erasmus 1996: 148-149; Wessels 1908: 386. 
from sale in execution have never included the debtor's home. In the individual debt enforcement process, the common law position has always been that a judgment creditor is obliged first to attach and execute against a debtor's movables before executing against his immovable property, for which a court order is required. ${ }^{76}$ However, a mortgagee may execute against hypothecated immovable property without first having to excuss the debtor's movables as long as he obtains a court order declaring the immovable property specially executable. ${ }^{77}$ Parate executie is not permissible as regards immovable property. ${ }^{78}$

Important procedural changes were brought about in order to alleviate the burden on courts. Legislative amendments were made and rules of court became applicable, which empowered a registrar of a high court and a clerk of the magistrate's court to grant default judgment against a debtor who did not respond to a summons or who did not enter an appearance to defend the matter. ${ }^{79}$ Legislation and rules of court also empowered a registrar of the high court to issue a writ of execution and a clerk of the magistrate's court to issue a warrant of execution, without an order of court, in respect of the immovable property of a judgment debtor against whom default judgment had been granted. ${ }^{80}$

\section{Developments based on recognition of the right to have access to adequate housing}

The introduction of a new constitution, including a bill of rights, brought about fundamental reform to South African jurisprudence and its legal system. This led to changes, in the individual debt enforcement process, in relation to execution against a debtor's home, through the recognition of the impact of everyone's right to have access to adequate housing, provided for in section 26(1) of the Constitution, which forms part of the Bill of Rights. Section 26(3) provides that no one may be evicted from their home without an order of court made after considering all the relevant circumstances. Section 26(2) obliges the state to take reasonable legislative and

76 In relation to the position according to Roman law, see Steyn 2015: 126 and references cited there. As regards South African law, see Rule 43 of the Magistrates' Courts Rules, as well as Van Loggerenberg 2011: commentary to Rule 43; and Rule 46(1) of the High Court Rules as amended by the Rules Board for Courts of Law in terms of sec 6 of the Rules Board for Courts of Law Act 107 of 1985 and approved by the Minister of Justice and Constitutional Development. In particular, see Amendment: Rules regulating the Conduct of the Proceedings of the Supreme Court of Appeal of South Africa: Rules regulating the Conduct of the Proceedings of the High Courts of South Africa; Government Notice R981 of 2010; GG 33689, 19 Nov 2010, discussed further at par 42 infra.

77 Colonial Mutual Life Assurance Society Ltd v Tilsim Investments (Pty) Ltd 1952 (4) SA 134 (C) 135. See, also, par 43 infra.

78 See, further, par 43 infra.

79 See Steyn 2012: pars $4432 \& 4442$ and references cited there.

80 Idem at pars $4433 \& 4443$ and references cited there. 
other measures within its available resources to achieve the progressive realisation of everyone's right to have access to adequate housing. ${ }^{81}$ The Constitutional Court interpreted and applied section 26 for the first time in Government of the Republic of South Africa $v$ Grootboom, ${ }^{82}$ a case that concerned the eviction of a community from private land. The court held, inter alia, that, at the very least, section 26(1) places a negative obligation on the state and all other persons to desist from preventing or impairing the right of access to adequate housing. ${ }^{83}$

In 2004, the Constitutional Court's judgment in Jaftha $v$ Schoeman heralded the implications of section 26 for execution against a debtor's home. This case concerned execution through the magistrate's court process against the state-subsidised homes of two indigent debtors in actions to obtain satisfaction of trifling, extraneous ${ }^{84}$ debts. The Constitutional Court held that execution against a debtor's home may constitute an unjustifiable infringement of section 26 of the Constitution. It concluded that section 66(1)(a) of the Magistrates' Courts Act was unconstitutional in that it was sufficiently broad to allow sales in execution to proceed in circumstances where they would not be justifiable in terms of section 36 of the Constitution. It directed certain words to be read into section 66(1)(a) with the effect that, where insufficient movables were found to satisfy a judgment debt, the creditor would need to approach a court to seek an order permitting execution against the immovable property of the judgment debtor. A court was required to consider all the relevant circumstances to evaluate whether, in the circumstances, execution would be justifiable in terms of section $36 .{ }^{85}$ The Constitutional Court stated that, in the absence of any abuse of court procedure, execution should ordinarily be permitted where a debtor had mortgaged his home to secure a debt. ${ }^{86}$ It also stated that balancing the parties' interests in accordance with section 36 should not be "an all or nothing process" but that there was a need to find "creative alternatives" which allow for debt recovery but which use the sale in execution of a debtor's home "only as a last resort". ${ }^{87}$

In late 2010, rules 45 and 46 of the High Court Rules were amended to bring the high court process into line with that applicable in the magistrates' courts after Jaftha $v$ Schoeman. A proviso, apparently only applicable to sub rule 46(1)(a)(ii), required a court, not a registrar, to issue a writ of execution against the primary residence of a judgment debtor and only after it has considered all the relevant circumstances. Close on the heels of this rule change, followed the delivery of the

81 The Housing Act 107 of 1997 and the Prevention of Illegal Eviction from and Unlawful Occupation of Land Act 19 of 1998, as well as other statutes, were enacted in furtherance of this obligation and the National Housing Code was issued in terms of the Housing Act.

82 Government of the Republic of South Africa v Grootboom 2001 (1) SA 46 (CC), hereafter referred to as Grootboom.

83 Grootboom at par 34.

84 In other words, the homes had not been mortgaged in favour of the judgment creditors.

85 Jaftha $v$ Schoeman at pars $44 \& 55$.

86 Idem at par 58.

87 Idem at par 59. 
Constitutional Court's judgment in Gundwana $v$ Steko, which concerned the validity of default judgment and a declaration of executability of mortgaged property by the registrar of the high court, issued post-Constitution but before the change in the High Court Rule 46(1). The effect of the judgment is that now, in every case in which execution is sought against a person's home, including where it has been mortgaged, a court, not a registrar, is required to undertake an evaluation, considering "all the relevant circumstances", to determine whether execution should be permitted. ${ }^{88}$ The Constitutional Court stated that due consideration should be given to the impact that execution might have on judgment debtors who are poor and at risk of losing their homes. It also stated that, before granting execution orders, courts should consider whether the judgment debt may be satisfied by reasonable alternative means ${ }^{89}$ During the period of the developments outlined above, various practice directives were issued in some divisions of the high court in order to guide courts and practitioners on how to conform to constitutional imperatives as interpreted and applied in the precedent-setting judgments..$^{90}$

The NCA, which came into full effect on 1 June 2007, with consumer protection and, notably, "promoting equity in the credit market by balancing the respective rights and responsibilities of credit providers and consumers" included in its main objectives, ${ }^{91}$ impacts significantly on the enforcement of credit agreements, including "mortgage agreements". ${ }^{92}$ The most recent Constitutional Court decision that has impacted fundamentally on home mortgagors' and mortgagees' rights is Nkata $v$ Firstrand Bank, which concerned the provisions contained in section 129(3) and (4) of the NCA. This case will be discussed below, after the main principles pertaining to mortgage and the NCA's regulation of mortgage debt enforcement have been set out.

\section{Mortgage}

South African law in relation to mortgage is founded upon the principles of Roman and Roman-Dutch law. ${ }^{93} \mathrm{~A}$ "mortgage bond" is a document which, when registered

88 Gundwana $v$ Steko at par 50.

89 Idem at par 53. Courts subsequently interpreted and applied the precedent established in Gundwana $v$ Steko in, eg, Nedbank v Fraser, FirstRand Bank Ltd v Folscher and Similar Matters 2011 (4) SA 314 (GNP); Standard Bank of South Africa Ltd v Bekker and Four Similar Cases 2011 (6) SA 111 (WCC); and Mkhize v Umvoti Municipality 2012 (1) SA 1 (SCA).

90 See Steyn 2012: 192, 285, 287 \& 301. See also, eg, ch 1017 of the Practice Manual of the South Gauteng Court, referred to by Van der Linde J in Firstrand Bank t/a First National Bank v Zwane 2016 (6) SA 400 (GJ), discussed at par 43 infra.

91 See $\mathrm{s} 3$ of the NCA.

92 A "mortgage agreement or a secured loan" constitutes a "credit transaction", which is a "credit agreement" regulated by the NCA; see s $8(4)(d)$. In s 1, a "mortgage agreement" is defined as "a credit agreement that is secured by the registration of a mortgage bond by the registrar of deeds over immovable property" and a "mortgage" is defined as "a mortgage bond registered by the registrar of deeds over immovable property that serves as continuing covering security for a mortgage agreement".

93 As set out in 23 supra. 
in the Deeds Registry in accordance with the provisions of the Deeds Registries Act 47 of 1937 , creates a right of security over immovable property, ${ }^{94}$ which is accessory to the principal obligation that it secures. ${ }^{95}$

Common types of mortgage bond are a kustingbrief; a covering bond; a collateral bond; a surety bond; an indemnity bond; and a participation bond. A kustingbrief is a bond passed by the purchaser of immovable property simultaneously with the transfer of the property into his name. ${ }^{96}$ The bond may be in favour of the seller, to secure payment of the purchase price, or a third party, such as a bank, to secure the repayment of a loan provided to the mortgagor to enable him to pay the purchase price. ${ }^{97}$ A covering bond is one which secures a debt, or debts, which will, or may, be incurred in the future. A collateral bond is one which is passed by the mortgagor to secure an obligation for which he has already provided security. A surety bond is one in which a surety secures his obligation to the creditor. The most likely forms of mortgage bond to feature in the context of forced sale of a debtor's home would be a kustingbrief or, possibly, a covering, collateral, or surety bond, in the case of a homeowner or a businessperson who has passed a mortgage bond over his home in order to secure personal or business debts.

A mortgage bond invariably contains, inter alia, the following particulars and terms: ${ }^{98}$ an acknowledgment of indebtedness by the mortgagor in favour of the mortgagee; a description of the cause of indebtedness and the amount owed; a statement of the interest rate applicable; the terms of repayment; and a "foreclosure clause" in terms of which it is agreed that, should the mortgagor breach the principal obligation or any other term contained in the mortgage bond, the principal debt together with interest will become payable immediately and the mortgagee will be entitled to institute action for payment and for an order declaring the mortgaged property specially executable.

Ordinarily, the parties agree that, if the debtor fails to pay any one instalment, the creditor will be entitled to demand the entire balance of the debt. This is termed an "acceleration clause". ${ }^{99}$ Thus, upon failing to pay a single instalment, the entire balance of the debt will become due for payment by the debtor, failing which the creditor will be entitled to enforce all the other terms of their contract. ${ }^{100}$ However, constitutional implications must also be borne in mind. In the case of a mortgagor missing a single instalment due in terms of a home mortgage, any limitation of his housing and other rights and, for that matter, any limitation of the creditor's

94 Lubbe \& Scott 2008: pars 324-398.

95 See Kilburn v Estate Kilburn 1931 AD 501.

96 Also mentioned in par 23 supra.

97 Lubbe \& Scott 2008: par 397.

98 Idem at pars $353 \& 360-366$.

99 Bradfield 2011: 436-437.

100 As was the position in ABSA Bank Ltd $v$ Ntsane 2007 (3) SA 554 (T), hereafter referred to as Absa $v$ Ntsane. See Absa v Ntsane pars 67-68, 81-82, 85, 91 \& 93-94. 
rights must accord with proportionality assessments required by section 36 of the Constitution. ${ }^{101}$ In ABSA v Ntsane, Bertelsmann $\mathrm{J}$ refused to grant judgment in the amount of the accelerated debt or an order of special executability in respect of the mortgaged home of the judgment debtors on the basis that it was regarded as an abuse of the court process to seek execution against a person's home in respect of a trifling arrear amount of R18,46. ${ }^{102}$ Since its coming into operation, the NCA regulates the enforcement of mortgage obligations, the consequences of which will be discussed below. ${ }^{103}$

The effect of the registration of a mortgage bond is that the mortgagor, who remains the owner, may use and enjoy the property. ${ }^{104}$ Where the mortgagor breaches any term of the mortgage bond, the mortgagee is not required first to execute against the movable property of the judgment debtor, as a judgment creditor is ordinarily required to do, but he is entitled to immediate execution against the mortgaged immovable property. ${ }^{105}$ This is the case even where there is no clause in the bond to this effect. However, he cannot execute against the mortgaged property without reference to the mortgagor or the court: he must first sue and obtain judgment on the mortgage bond and obtain a court order declaring the mortgaged immovable property specially executable. ${ }^{106}$ A parate executie clause, permitting the mortgagee to take possession of the mortgaged immovable property and to sell it without reference to the mortgagor or the court, is invalid and therefore void. ${ }^{107}$ Likewise, a forfeiture clause providing that, upon the mortgagor's default, the mortgagee will become the owner of the mortgaged property, is void. ${ }^{108}$ However, the mortgagee may purchase or, as it is termed, "buy in" the mortgaged property at the sale in execution and may set off the amount due under the bond against the purchase price. ${ }^{109}$ If the purchase price is less than the amount due under the bond, the mortgagee still has a claim against the mortgagor for the balance. In other words, the mortgagor will nevertheless

101 See Steyn 2012: par 32 3; Brits 2013a: 183-184; Brits 2016: 89-91; and the reasoning expounded by Gorven J in Firstrand Bank Ltd v Mdletye 2016 (5) SA 550 (KZD) at pars 14-17.

102 ABSA v Ntsane at par 97.

103 See par 44 infra.

104 Lubbe \& Scott 2008: par 360.

105 Colonial Mutual Life Assurance Society Ltd v Tilsim Investments (Pty) Ltd 1952 (4) SA 134 (C) 135.

106 Lubbe \& Scott 2008: par 368.

107 Idem at par 368; Iscor Housing Utility Co v Chief Registrar of Deeds 1971 (1) SA 613 (T), approved in Bock v Duburoro Investments (Pty) Ltd 2004 (2) SA 242 (SCA) at par 7, Citibank NA $v$ Thandroyen Fruit Wholesalers CC 2007 (6) SA 110 (SCA) at par 13, and Nedcor Bank Ltd v SDR Investment Holdings Co (Pty) Ltd 2008 (3) SA 544 (SCA). This was also the position at the time of Grotius; see 23 supra.

108 As was the position in Roman law, after the passing of the lex commissoria in AD 320.

109 Lubbe \& Scott 2008: par 368; Smiles' Trustee v Smiles 1913 CPD 739; ABSA Bank Ltd v Bisnath NO 2007 (2) SA 583 (D), hereafter referred to as ABSA v Bisnath. See, also, Cronje v Hillcrest Village (Pty) Ltd 2009 (6) SA 12 (SCA). 
be liable for the shortfall. ${ }^{110}$ Worthy of mention, in this context, is a proposal for the amendment of the Uniform Rules of Court and the Magistrates' Courts Rules, respectively, to provide for personal service upon a debtor of a notice of attachment of immovable property that is his or her primary residence and for a court to have the power to set a reserve price for the sale in execution of the debtor's residence. ${ }^{111}$ This would be to avoid debtors' homes being sold for exceedingly low prices. ${ }^{112}$

A common law principle applicable is that a mortgagor may redeem the mortgaged property by paying the total amount outstanding and costs, even after a sale in execution has taken place. It has been held that this applies right up until the registration of the property in the name of the purchaser in execution. ${ }^{113}$ This aspect of the common law has been referred to in various reported cases and different contexts, and, recently, in the interpretation and application of provisions of the NCA in matters concerning execution against a mortgagor's home. ${ }^{114}$

\section{The NCA's regulation of enforcement of a mortgage bond}

As stated above, the provisions of the NCA apply to a mortgage bond. ${ }^{115}$ The NCA limits the powers of a "credit provider" to enforce a credit agreement by, inter alia, requiring notices to be issued to the debtor, termed the "consumer", advising him of his rights and options available under the NCA and prescribing the lapse of minimum periods between the various stages of the debt enforcement process. ${ }^{116}$ The NCA forbids the granting of "reckless credit" by credit providers. ${ }^{117}$ It also provides an alternative debt relief measure for an over-indebted consumer by providing for debt counselling, debt review, and, where appropriate, debt restructuring in terms of which it is envisaged that a consumer will be required eventually to fulfil all of his or her financial obligations. ${ }^{118}$

110 In Rossouw $v$ FirstRand Bank, it was held that s 130(2) of the NCA does not apply to mortgage bonds. ABSA v Bisnath at 589-590 is authority for the proposition that, if the mortgagee thereafter sells the property to a third party for a price higher than the total cost that he has been occasioned, the mortgagee must account to the mortgagor for any ultimate profit arising from his subsequent transactions.

111 See the invitation by the Rules Board for Courts of Law, Republic of South Africa, for public comment on the proposed Rule 46A of the High Court Rules and Rule 43B of the Magistrates' Courts Rules; http://www.justice.gov.za/rules_board/invite/2016-SalesExecution-HCR46-MCR43. $p d f$ (accessed 12 Aug 2017).

112 See Brits 2013b with reference to Nxazonke v Absa Bank (18100/2012) [2012] ZAWCHC 184 (4 Oct 2012).

113 See Nkata $v$ FirstRand Bank (CC) at par 131 and Nkata $v$ FirstRand Bank (WCC) at par 53.

114 See, eg, authorities cited and discussed in Nedbank v Fraser at par 40. See, also, Brits 2012: 48; Brits 2013a: 167.

115 See par 42 at n 92 supra.

116 See ss $129 \& 130$ of the NCA.

117 See ss $80-84$ of the NCA.

118 See $\mathrm{s} 3$ of the NCA. 
In terms of section 130 of the NCA, a credit provider cannot enforce a credit agreement unless the consumer has been in default under that credit agreement for at least twenty business days. ${ }^{119}$ The credit provider must then deliver to the consumer a notice as contemplated in section 129(1)(a). ${ }^{120}$ Such notice must draw the consumer's attention to the default and propose that he consults a debt counsellor, ${ }^{121}$ alternative dispute resolution agent, ${ }^{122}$ consumer court, ${ }^{123}$ or ombud with jurisdiction ${ }^{124}$ so that they may resolve any dispute under the agreement or develop and agree on a plan to bring the payments under the agreement up to date. ${ }^{125}$

Section 129(3) permits a consumer who has fallen into default, at any time before the credit provider has cancelled the agreement, to "reinstate" or "remedy a default in" such agreement by paying all arrears and prescribed charges and costs. ${ }^{126}$

Where at least ten business days have elapsed after delivery of the section 129(1)(a) notice, the court may hear the matter. ${ }^{127}$ This is as long as there is no issue regarding the credit agreement pending before the National Consumer Tribunal ${ }^{128}$ or the matter is not already serving before a debt counsellor, alternative dispute resolution agent, consumer court or the ombud with jurisdiction. ${ }^{129}$ The failure to issue a section 129 notice in compliance with the NCA will prevent a mortgagee from obtaining judgment against a debtor upon the latter's default and, consequently, an order of executability in respect of the mortgaged property. ${ }^{130}$

The first reported judgment concerning enforcement of acceleration clauses in home mortgage bonds, after the coming into operation of the NCA in 2007, was FirstRand Bank Limited v Maleke; FirstRand Bank Limited v Motingoe; Peoples

119 Section 130(1).

120 See, also, s 129(1)(b).

121 "Debt counsellors" must be registered in terms of s 44 of the NCA.

122 An "alternative dispute resolution agent", according to $\mathrm{s} 1$, is "a person who provides services to assist in the resolution of consumer credit disputes through conciliation, mediation or arbitration".

123 In terms of $\mathrm{s} 1$ of the NCA, a "consumer court" is defined as "a body of that name, or a consumer tribunal established by provincial legislation".

124 In terms of s 1 of the NCA, an "ombud with jurisdiction" in respect of any particular dispute arising out of a credit agreement in terms of which the credit provider is a "financial institution" as defined in the Financial Services Ombud Schemes Act 37 of 2004 means an "ombud" or the "statutory ombud", as those terms are respectively defined in that Act, who has jurisdiction in terms of that Act to deal with a complaint against the financial institution.

125 Section 129(1)(a).

126 The wording of s 129(3) was amended by s 32(a) of the National Credit Amendment Act 19 of 2014, which came into effect on 13 March 2015. This will be discussed further, infra.

127 Section 130(1)(a). The consumer must also not have responded or rejected the credit provider's proposals; see s 130(1)(b).

128 Section 130(3)(b).

129 Section 130(3)(c)(i).

130 See Dwenga $v$ First Rand Bank Ltd (EL 298/11, ECD 298/11) [2011] ZAECELLC 13 (29 Nov 2011), hereafter referred to as Dwenga $v$ FirstRand Bank. See, also, the minority judgment of Jafta $\mathrm{J}$ in Nkata $v$ Firstrand Bank (CC) at pars 163 \& 166-175. 
Mortgage Ltd v Mofokeng; FirstRand Bank Limited v Mudlaudzi. ${ }^{131}$ The court refused to grant default judgment and orders of special executability against four mortgaged homes, regarding it as being more appropriate for the recently introduced debt review process to be explored as an alternative before judgment was granted and execution was permitted against the defendants' homes. ${ }^{132}$

Recently, in Nkata v FirstRand Bank (CC), ${ }^{133}$ the majority of the Constitutional Court delivered a judgment in which it interpreted and applied section 129(3) and (4) of the NCA in a way that has significant implications for parties to mortgage agreements. As mentioned above, section 129(3) allows a debtor to "reinstate" or to "remedy a default in" a credit agreement by paying the arrears and certain prescribed charges and costs. ${ }^{134}$ Section 129(4) limits the circumstances in which reinstatement may occur. Section 129(4)(b) provided that "[a] credit provider may not re-instate a credit agreement after ... (b) the execution of any other court order enforcing that agreement". ${ }^{135}$ The majority, per Moseneke DCJ, interpreted this to mean that reinstatement of the credit agreement is prevented only once "the proceeds from a sale in execution have been realised". ${ }^{136}$ The effect is that a mortgagor may remedy his or her default and reinstate the mortgage bond by paying the arrears and prescribed charges and costs at any point until the registration of title in the name of the purchaser at the sale in execution. ${ }^{137}$ The Constitutional Court confirmed that reinstatement in terms of section 129(3) occurs by operation of law as soon as the arrears and prescribed charges and costs have been paid. ${ }^{138}$ Another significant aspect of the decision is the declaration that reinstatement renders invalid a default judgment previously obtained. ${ }^{139}$

The precedent established in Nkata $v$ Firstrand Bank (CC) has been applied in two reported cases. In Firstrand Bank Ltd v Mdletye, ${ }^{140}$ the court granted judgment against the mortgagors in the amount of the accelerated outstanding debt of R275 315,04,

131 FirstRand Bank Limited v Maleke; FirstRand Bank Limited v Motingoe; Peoples Mortgage Ltd v Mofokeng; FirstRand Bank Limited v Mudlaudzi 2010 (1) SA 143 (GSJ), hereafter referred to as FirstRand Bank v Maleke.

132 Idem at pars 6, $16 \& 17-24$.

133 Nkata $v$ FirstRand Bank (CC).

134 Nkata $v$ Firstrand Bank concerned the provisions as they were worded before their amendment. The amended s 129(3) no longer uses the term "reinstate", which was used in the original version of the provision, but it provides for a consumer to "remedy a default" in a credit agreement, which, it is submitted, essentially amounts to the same thing. See Steyn \& Sharrock 2017: 500; $c f$ Brits, Coetzee \& Van Heerden 2017.

135 The amended s 129(4) now states that "[a] credit provider may not re-instate or revive a credit agreement after ... (b) the execution of any other court order enforcing that agreement". There is no change to the meaning of the provision; see Steyn \& Sharrock 2017: $500 \& 512$.

136 Nkata v FirstRand Bank (CC) at par 131.

$137 C f$ the common law right of redemption and authorities cited and referred to at par 43 supra.

138 Nkata $v$ FirstRand Bank (CC) at par 105.

139 Idem at pars $76 \& 137$.

140 Firstrand Bank Ltd v Mdletye 2016 (5) SA 550 (KZD), hereafter referred to as Firstrand Bank v Mdletye. 
plus interest. However, it refused to grant the application to declare the immovable property executable and adjourned it sine die, directing that the application could not be set down sooner than six months from the date of judgment. ${ }^{141}$ The purpose of this was to provide the mortgagors with the opportunity to remedy their default in terms of section 129(3) of the NCA in order to avoid execution against their home. ${ }^{142}$ In Firstrand Bank t/a First National Bank $v$ Zwane, ${ }^{143}$ the court extended protection even further to the mortgagors by adjourning sine die the applications both for the granting of default judgment in the accelerated amount of the debt and for declarations of special executability of the mortgaged properties in question. The court also directed that the applications could not be set down earlier than four months from then. ${ }^{144}$ Bearing in mind the Practice Manual applicable in its area of jurisdiction, the court applied the rationale that, if, in each case, it granted default judgment in the amount of the accelerated debt and postponed only the application for the declaration of executability of the mortgaged property, this would leave the mortgagor exposed to the possibility of the mortgagee executing against the former's movable property and other assets. This, the court observed, might defeat the purpose of the postponement by jeopardising the capacity of the mortgagor to reinstate the mortgage bond by paying the arrears and prescribed charges and costs in terms of section 129(3) of the NCA. ${ }^{145}$

\section{Conclusion}

Clearly, the South African common law principles relating to mortgage and those applicable in the context of execution against a mortgagor's immovable property that constitutes his or home, are rooted in Roman Dutch law. A number of fundamental Roman-Dutch principles feature prominently in contemporary South African common law. For example, as was the case in the developed Roman-Dutch law, a mortgagor remains owner of the mortgaged property; acceleration clauses are permissible and are frequently relied upon by mortgagees after a mortgagor's default; parate executie clauses are invalid in mortgage agreements in respect of immovable property and a judicial sale in execution is required. A pactum commissorium is invalid and therefore a mortgagee may not become owner upon a mortgagor's default, but may "buy in" at a sale in execution. ${ }^{146} \mathrm{~A}$ mortgagor may "redeem" the mortgaged property by paying

141 Idem at par 18.

142 Idem at pars 13-17.

143 Firstrand Bank t/a First National Bank v Zwane 2016 (6) SA 400 (GJ), hereafter referred to as Firstrand Bank $v$ Zwane.

144 Idem at pars $28 \& 31$.

145 Idem at pars 5-7 \& 23-24.

146 See par 23 supra. 
the total outstanding debt and costs at any time until registration of transfer of title, that is, even after a sale in execution has been held. ${ }^{147}$

Certain Roman-Dutch procedural rules and practices may be identified as generally tending towards affording a measure of protection for the home of a debtor against execution by a creditor. These were rules which encouraged extra-judicial settlement negotiations and required personal service of summonses, four defaults before default judgment could be obtained in respect of a claim involving immovable property, and a more protracted procedure for execution against immovable, as opposed to movable, property. Exacting requirements were imposed in order to maximise the price obtained at a judicial sale of immovable property. There was also the rule that a creditor could not levy execution upon immovable property of great value for small debts unless the property was indivisible. ${ }^{148}$

The same procedural rules and practices were not evident in the pre-Bill of Rights South African law but may be viewed as being more in line with the contemporary approach. For example, the requirements and procedure for a creditor to obtain default judgment were made more debtor-oriented by the decision in Jaftha $v$ Schoeman and by an amendment to rule 46(1) of the High Court Rules as well as by the decision in Gundwana v Steko. ${ }^{149}$ Jaftha $v$ Schoeman also established precedent to the effect that execution may not be levied against a person's home in respect of a trifling debt. ${ }^{150}$ Recently, proposals have also been made for the following: personal service of a notice of attachment of immovable property that constitutes a debtor's primary residence; and for the court, in appropriate circumstances, to set a reserve price for a sale in execution of a debtor's primary residence. ${ }^{151}$

Since the enactment of the NCA, the position is significantly different from that which applied at the time of the decision in Absa v Ntsane, in 2006. Then, Bertelsmann $\mathrm{J}$ found that it was an abuse of process for the mortgagee to seek to enforce an acceleration clause in the mortgage bond when the arrear amount was trifling. In the circumstances, the court granted judgment in an amount calculated with reference to the arrears only, and not the capital amount of the loan, and it refused to declare the mortgaged property specially executable. Now, section 129(3) and (4) of the NCA applies to counter the harsh consequences of enforcement of an acceleration clause. Most significantly, in Nkata v Firstrand Bank (CC), the Constitutional Court confirmed that a mortgagor may remedy his or default by paying the arrears and prescribed costs at any time before the registration of title in the name of the purchaser in execution. This may occur even after a sale in execution has been held. The important difference between reinstatement, in terms of the NCA,

147 See par 43 supra.

148 See par 22 supra.

149 See par 42 supra.

150 Ibid.

151 See par 43 supra. 
and redemption, in terms of the common law, based on Roman-Dutch principles, is that, for a mortgagor to redeem the mortgaged property, he or she had to pay the total outstanding amount of the debt, together with costs, at any time before registration of transfer of title to the purchaser in execution. Now, having considered "all of the relevant circumstances", as a court is required to do, where appropriate, it may afford the mortgagor an opportunity to reinstate, or remedy his or her default, in terms of section 129(3) of the NCA, by simply postponing, even sine die, an application by the mortgagee for judgment in the accelerated debt amount and/or an application for a declaration of special executability of the mortgaged home.

Wessels observed that "tenderness towards the defendant always formed a marked feature in the procedure of the Dutch courts ..." ${ }^{152} \mathrm{He}$ also commented that certain Roman-Dutch principles were "favourable" to a mortgagor. ${ }^{153}$ Various aspects of the Roman-Dutch principles and procedural rules may be regarded as reflecting an approach that execution against immovable property should occur only as a last resort. These may be viewed as being more in line with contemporary, constitutional imperatives to balance the various rights applicable in the context of execution against a debtor's home.

\section{BIBLIOGRAPHY}

Bradfield, GB (2011) Christies The Law of Contract in South Africa 6ed (Durban)

Bertelsmann, E et al Nagel C (ed) (2008) Mars The Law of Insolvency in South Africa 9 ed (Cape Town)

Brits, R (2012) Mortgage Foreclosure under the Constitution: Property, Housing and the National Credit Act (LLD, Stellenbosch University)

Brits, R (2013) "Purging mortgage default: Comments on the right to reinstate credit agreements in terms of the National Credit Act" Stell LR 24: 165-184

Brits, R (2013) "Sale in execution of property at an unreasonably low price indicates abuse of process - Nxazonke v ABSA Bank Ltd" THRHR 76: 451-458

Brits, R (2016) Real Security Law (Cape Town)

Brits, R, Coetzee, H \& Van Heerden, C (2017) "Re-instatement of credit agreements in terms of the National Credit Act 34 of 2005: Quo vadis?" THRHR 80: 177-197

Calitz, J (2009) A Reformatory Approach to State Regulation of Insolvency Law in South Africa (LLD, University of Pretoria)

Calitz, J (2010) "Historical overview of state regulation of South African insolvency law" Fundamina 16(2): 1-27

De Vos, W (1992) Regsgeskiedenis (Cape Town)

Du Bois, F (ed) (2007) Willes Principles of South African Law 9 ed (Cape Town) 


\section{EXECUTION AGAINST A DEBTOR'S HOME IN TERMS OF ROMAN-DUTCH LAW}

Erasmus, HJ (1991) "Historical foundations of the South African law of civil procedure" SALJ 108: $265-276$

Erasmus, HJ (1996) "The interaction of substantive law and procedure" in R Zimmerman \& D Visser (eds) Southern Cross: Civil Law and Common Law in South Africa (Oxford): 141-161

Eckard, CF (1990) Principles of Civil Procedure in the Magistrate's Courts (tr M Dendy 2 ed, Cape Town)

Evans, RG (2008) A Critical Analysis of Problem Areas in Respect of Assets of Insolvent Estates of Individuals (LLD, University of Pretoria)

Fagan, E (1996) "Roman-Dutch law in its South African historical context" in R Zimmerman \& D Visser (eds) Southern Cross: Civil Law and Common Law in South Africa (Oxford): 33-64

Girvin, S (1996) "The architects of the mixed legal system" in Zimmerman R \& Visser D (eds) Southern Cross: Civil Law and Common Law in South Africa (Oxford): 95-139

Glover, GB (2003) The Doctrine of Duress in the Law of Contract and Unjustified Enrichment in South Africa (PhD, Rhodes University)

Grotius H (1903) Inleidinge tot de Hollandsche Rechtsgeleerdheid (tr AFS Maasdorp The Introduction to Dutch Jurisprudence of Hugo Grotius) (Cape Town)

Lee, RW (1953) An Introduction to Roman-Dutch Law 5 ed (Oxford)

Lubbe, GF \& Scott, TJ (2008) "Mortgage and Pledge" in WA Joubert \& JA Faris (eds) LAWSA 17(2) (Durban): pars 324-452

Roestoff, M (2002) 'n Kritiese Evaluasie van Skuldigverligtingsmaatreëls vir Individue in die Suid-Afrikaanse Insolvensiereg (LLD, University of Pretoria)

Roestoff, M(2005) "Skuldverligtingsmaatreëls vir individue in die Suid Afrikaanse insolvensiereg: 'n Historiese ondersoek" (Deel II) Fundamina 11(1): 78-111

Steyn, L (2012) Statutory Regulation of Forced Sale of the Home in South Africa (LLD, University of Pretoria)

Steyn, L (2015) "Protection against forced sale of a debtor's home in the Roman context" Fundamina 21(1): 119-141

Steyn, L \& Sharrock R (2017) "Remedying mortgage default: Nkata v Firstrand Bank Limited" SALJ 134: 498-513

Van der Keessel, DG (1884) Theses Selectae Juris Hollandici et Zelandici (tr CA Lorenz Select Theses on the Laws of Holland and Zeeland 2 ed) (Cape Town)

Van der Linden, J (1891) Regtsgeleerd, Practicaal, en Koopmans Handboek, ten dienste van Regters, Practizijns, Kooplieden, en Allen, Die Een Algemeen Overzicht van Regtskennis Verlangen (tr H Juta Institutes of Holland or Manual of Law, Practice, and Mercantile Law for the Use of Judges, Lawyers, Merchants and All Those Who Wish to have a General View of the Law 2 ed) (Cape Town)

Van Loggerenberg DE (2011) Jones \& Buckle The Civil Practice of the Magistrates' Courts in South Africa 10 ed (Cape Town)

Voet Commentarius ad Pandectas (1957) (tr P Gane The Selective Voet being the Commentary on the Pandects (Durban))

Wessels, JW (1908) History of the Roman-Dutch Law (Grahamstown)

Zimmermann, R (1996) "Good faith and equity" in R Zimmermann \& D Visser (eds) Southern Cross: Civil Law and Common Law in South Africa (Oxford): 217-260 


\section{LIENNE STEYN}

\section{Websites}

Invitation by the Rules Board for Courts of Law, Republic of South Africa, for public comment on the proposed Rule 46A of the High Court Rules and Rule 43B of the Magistrates' Courts Rules (accessed 12 Aug 2017); available at http://www.justice.gov.za/rules_board/ invite/2016-SalesExecution-HCR46-MCR43.pdf

Practice Manual of the South Gauteng Court (current version accessed 26 Aug 2017) available at https://johannesburgbar.co.za/wp-content/uploads/Practice-Manual-Gauteng-LocalDivision-JANUARY-2017-FINAL-6-Feb-rev-1.pdf

\section{Legislation}

\section{Old legislation}

Charter of Justice 1827

Charter of Justice 1832

Codex Theodosianus 438 AD

Handvest of Alkmaar 1254

Lex Commissoria 320 AD

Ordinance 72 of 1830

Ordinance on Civil Procedure of 1580

Perpetual Edict of 4 October 1540

Placaat der 40ste Penning of 22 December 1598

Placaat of Charles V of 10 May 1529

Politique Ordonantie of 1580

Proclamation 2 of September 1819

\section{Contemporary legislation}

Housing Act 107 of 1997

National Credit Act 34 of 2005

National Credit Amendment Act 19 of 2014

Prevention of Illegal Eviction from and Unlawful Occupation of Land Act 19 of 1998

Rules Board for Courts of Law Act 107 of 1985

\section{Rules of Court}

High Court Rules, formally referred to as Uniform Rules of Court

Magistrates' Courts Rules

Amendment: Rules regulating the Conduct of the Proceedings of the Supreme Court of Appeal of South Africa: Rules regulating the Conduct of the Proceedings of the High Courts of South Africa; Government Notice R981 of 2010; GG 33689, 19 Nov 2010 


\section{EXECUTION AGAINST A DEBTOR'S HOME IN TERMS OF ROMAN-DUTCH LAW}

\section{Cases}

ABSA Bank Ltd v Bisnath NO 2007 (2) SA 583 (D)

ABSA Bank Ltd v Ntsane 2007 (3) SA 554 (T)

Bock v Duburoro Investments (Pty) Ltd 2004 (2) SA 242 (SCA)

Citibank NA v Thandroyen Fruit Wholesalers CC 2007 (6) SA 110 (SCA)

Colonial Mutual Life Assurance Society Ltd v Tilsim Investments (Pty) Ltd 1952 (4) SA 134 (C)

Cronje v Hillcrest Village (Pty) Ltd 2009 (6) SA 12 (SCA)

Dwenga $v$ First Rand Bank Ltd (EL 298/11, ECD 298/11) [2011] ZAECELLC 13 (29 November 2011)

FirstRand Bank Limited v Maleke; FirstRand Bank Limited v Motingoe; Peoples Mortgage Ltd v Mofokeng; FirstRand Bank Limited v Mudlaudzi 2010 (1) SA 143 (GSJ)

Firstrand Bank Ltd v Mdletye 2016 (5) SA 550 (KZD)

FirstRand Bank Ltd v Folscher and Similar Matters 2011 (4) SA 314 (GNP)

Firstrand Bank t/a First National Bank v Zwane 2016 (6) SA 400 (GJ)

Government of the Republic of South Africa v Grootboom 2001 (1) SA 46 (CC)

Gundwana v Steko Development CC 2011 (3) SA 608 (CC)

Iscor Housing Utility Co $v$ Chief Registrar of Deeds 1971 (1) SA 613 (T)

Jaftha v Schoeman; Van Rooyen v Stoltz 2005 (2) SA 140 (CC)

Kilburn v Estate Kilburn 1931 AD 501

Mkhize v Umvoti Municipality 2012 (1) SA 1 (SCA)

Nedbank Ltd $v$ Fraser and Four Similar Cases 2011 (4) SA 363 (GSJ)

Nedcor Bank Ltd v SDR Investment Holdings Co (Pty) Ltd 2008 (3) SA 544 (SCA)

Nkata v FirstRand Bank Limited 2014 (2) SA 412 (WCC)

Nkata $v$ FirstRand Bank Limited 2016 (4) SA 257 (CC)

Nxazonke v Absa Bank (18100/2012) [2012] ZAWCHC 184 (4 October 2012)

Rossouw v FirstRand Bank Ltd t/a FNB Homeloans (Formerly First Rand Bank of South Africa Ltd) 2010 (6) SA 439 (SCA)

Smiles'Trustee v Smiles 1913 CPD 739

Standard Bank of South Africa Ltd v Bekker and Four Similar Cases 2011 (6) SA 111 (WCC) 